\title{
VISUALIZING G30S/PKI TRAGEDY THROUGH INTERACTIVE PROJECTOR MEDIA AT MONUMEN PANCASILA SAKTI
}

\author{
Yiesha Tabina ${ }^{1}$ \\ Mita Purbasari ${ }^{2}$
}

Accepted May.23, 2021; Approved November. 17, 2021

\begin{abstract}
The G3oS/PKI incident is an event that continues to imprint in the hearts of all Indonesian people because it is closely related to the Lubang Buaya incident, which is located in front of the Pancasila Sakti Monument. This large building is usually visited by students just for school assignments, even though in it lies the story of the struggle of the Indonesian people against communism. The quiet and cold atmosphere inside the monument makes visitors pass through dioramas and the hallways just like that. To spread the essential historical event, we need a way to change the stereotype that museums are boring. In this study, projection mapping is used inside the Pancasila Sakti Monument to give visitors a new sensation and experience through visuals. The research method uses qualitative data collection techniques in the form of location observations, interviews with the head of the research object guidance, and several visitors. The results of this project are interactive projections in the form of moving animated visuals that can be interacted with so that visitors get a real story experience. It is hoped that with the use of interesting animation, museums in Indonesia can compete with other places visited by many young people.
\end{abstract}

Keywords: visual; G3oS/PKI; monument Pancasila Sakti; projection interactive; youngsters

${ }^{1}$ Yiesha Tabina is an alumni at Graphic Design and New Media Program University Bina Nusantara (BINUS) Jakarta.

${ }^{2}$ Mita Purbasari is a lecturer at Graphic Design and New Media Program.University Bina Nusantara (BINUS) Jakarta. e-mail : yiesha.tabina@binus.ac.id

e-mail:mitawahid@binus.edu 


\section{Introduction}

A museum is defined as a building or institution that stores and displays artistic, historical, scientific, or cultural items. Museum collections are priceless and of great historical value (Widaningsih, 2010). Even so, the museum has stereotypes of ancient, old, and haunted. No wonder people hardly visit museums (Astari, 2019). RB also said on a website called muspen. kominfo. go.id that museum revitalization is essential. Not only to give a modern impression to the museum but also to educate the nation, raise the spirit and love for the homeland, and strengthen national resilience.

Visitors currently only visit museums when needed, such as when they get assignments from school. There are several types of museums in Indonesia, such as the Museum of Archeology, Art, History, Ethnography, Natural History, Science, Geology, Industry, and Military (Hamidi, 2020, Daniwati, 2015, Tjahjopurnomo, R. et al., 2011). Monumen Pancasila Sakti, which was created to commemorate the September 30 movement, or the G30S PKI (Indonesian Communist Party), is one of Indonesia's history museums.

Monumen Pancasila Sakti was built to prove that Pancasila will not be challenged by any rebellion attempt and will remain the legitimate state ideology (Damm, 2017). PKI kidnapped and eventually killed six generals of the Indonesian army, an army captain suspected of being the Commander of the Indonesian National Armed Forces (ABRI) General AH. Nasution, Ade Irma Suryani (the 3-year-old daughter of General AH. Nasution, and a security guard at the residence of Deputy Prime Minister J. Leimena (Krismantari, et al., 2015). The story of the G30S PKI rebellion is visualized with dioramas that display how ruthless PKI's actions were back then. (Retno, 2019). Monumen Pancasila Sakti was built not only to commemorate the September 3oth movement, but also to serve as a reminder to future generations.

Sadly, not many people come to explore the museum. On weekdays, the number of visitors ranges from 100 to 300 , and on weekends (especially before September 30th) it varies from 1000 to 1300. (Abdalla, 2017, Vinta \& Septiasputri, 2020). Based on Winarsih, Head of Monumen Pancasila Sakti, the arrival of visitors on weekdays is mostly high schoolers visiting for their school assignments. Meanwhile, from the results of a visit to the location (four days after the Pancasila Sanctity Day), Monumen Pancasila Sakti looked quite packed. Visitors varied from high school students to adults. Observing the behavior of visitors at that time was like seeing humans walking without enthusiasm. They seemed like they don't want to explore the museum further. The atmosphere of this museum is somewhat quiet, without decorations, empty, and hollow. The walls, cabinets, floors, and everything else in the room are all the same color. The room's shape is consistent and monotonous. That explains why visitors appeared uninterested in the actual artefacts; they simply walked and looked around. (Figure 1 and 2).

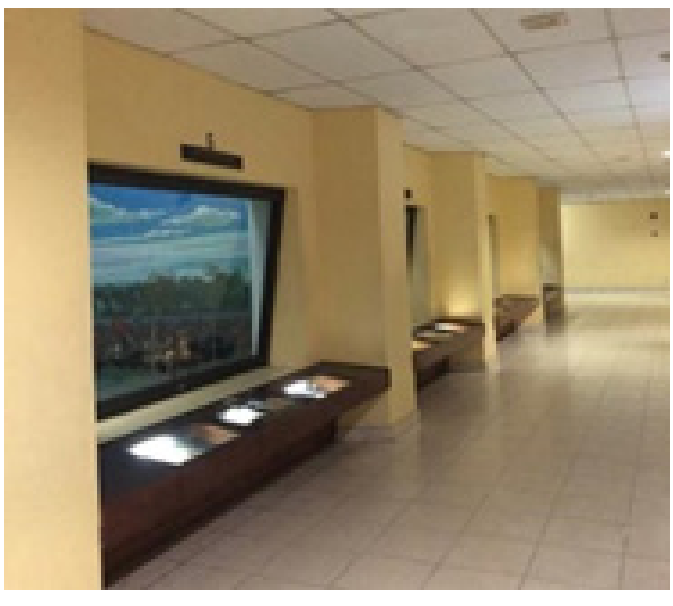

Figure 1. Diorama in Museum (Source: Tabina, 2020) 


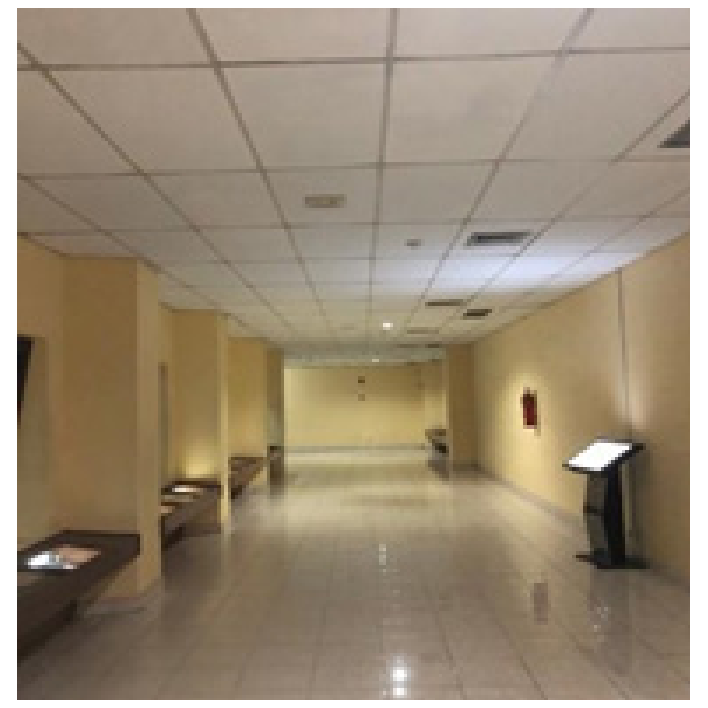

Figure 2. Hallway inside Museum (Source: Tabina, 2020)

According to President Joko Widodo in one of his speeches, Pancasila has become a defense in the battle for colonization of other ideologies. (Kusuma, 2019). Many ideologies tried to end Pancasila, and one of them is Communist. The Indonesian Communist Party (PKI) has massacred thousands of innocent people. This demonstrates how sadistic and brutal communists were back then, and how it affected people's trust in their leaders and Pancasila as an ideology (Burlian, 2016). Therefore, the existence of this museum is crucial because it keeps traces of history that put the lives of this nation at risk to maintain its dignity with blood and self-respect that upholds the values of God, unity, and community life.

As such, it is necessary to change the atmosphere of the space that can provide interaction between visitors and existing historical objects. It is hoped that it will provide an interesting, beautiful, accurate visual scene, and a different experience in each section so that people will voluntarily visit this history museum, especially millennial youth, junior and senior high school students, aged 13-18 years. Children's cognitive, social, moral, and personality abilities have entered the adult mindset at this age and have no difficulties receiving new information (Chusniyah, 2015).

\section{Methodology}

This study uses a qualitative method by conducting literature studies and references about museums in general, Monumen Pancasila Sakti in particular, digital media (animation, interactive animation, projection mapping), and design. The main research was obtained from conducting interviews with Winarsih, as the head of Monumen Pancasila Sakti, Edi Bawono as the Head of the Sub-Division of Guidance and Information of Monumen Pancasila Sakti and several visitors to ask about their experiences at the museum.

A direct visit to Monumen Pancasila Sakti is done to get the experience when visiting, to see firsthand the atmosphere there, the reactions and behavior of visitors inside the museum. This is essential to do to gain insight from the location and understand what is going on and what needs to be done to make Monumen Pancasila Sakti more recognizable.

This research and project mapping is limited to 1 . Interactive media platforms, 2. The concentration of the project is on the second floor of the museum as it is the most important part of the museum in the scene of the night story of the kidnapping of the generals.

\section{Result and Discussion}

\section{Projection Mapping Definition}

Cooper (2010) explains that projection is a form of technology that projects an image onto a surface or platform. The aim of projection mapping is to make visitors' experiences more interactive through visual stimulation. For 
this project, it was decided to use projection mapping as an animation platform, as the animation will be projected onto a wall in the Museum Hallway. Visitors can interact with the projection by tapping the wall or swiping the layer.

Based on an interview with Major Edi Bawono, it is told that Monumen Pancasila Sakti has 3 parts, which are Sumur Maut, Museum Pengkhianatan PKI, and Museum Paserban. All three have different artifacts and the position of the artifacts will determine where the projection will be placed. From an explanation of the details of each museum and the position of the diorama aisles, Museum Paserban became the focus of making the projection mapping. This building is divided into two parts, namely based on chronological order and the kidnapping itself.

\section{Story Concept}

Based on the diorama in Museum Paserban located at Monumen Pancasila Sakti, the chronology of the events of the PKI G30S is starting with the preparation meeting for the rebellion, volunteer military training, throwing bodies into the hole, securing Halim Perdanakusumah airfield, excavation and retrieval of the body remains from the pit, as well as burial ceremonies. The event took place from October 4 to October 5, 1965. The second part was the kidnapping. The diorama is about the kidnappings of General A.H Nasution, Lieutenant General Ahmad Yani, Major General Suprapto, Major General M.T Haryono, Major General S. Parman, Brigadier General D.I Pandjaitan, Brigadier General Sutoyo, and First Lieutenant Pierre Tendean. In addition, there are two additional dioramas, namely the shooting of Aipda KS Tubun and Adik Irma Suryani, daughter of A.H Nasution.

From these two sections, the research focuses on the kidnapping of A.H Nasut- ion which also involved Pierre Tendean and Ade Irma. With the selection of the kidnapping that took place at $\mathrm{AH} \mathrm{Na}-$ sution's residence, the video mapping shows several characters that match the events that occurred, such as AH Nasution, Pierre Tendean, Johanna (Nasution's wife), Ade Irma, Mardiah (Nasution's sister) and several others. soldiers as representatives of the Cakrabirawa troops.

\section{Project Location}

The projection will be displayed in a long corridor, directly in front of the kidnapping diorama. The kidnapping diorama is located on the second floor. A long blank wall opposite the diorama allows visitors to see the diorama while interacting with the projection as seen in Figure 3.

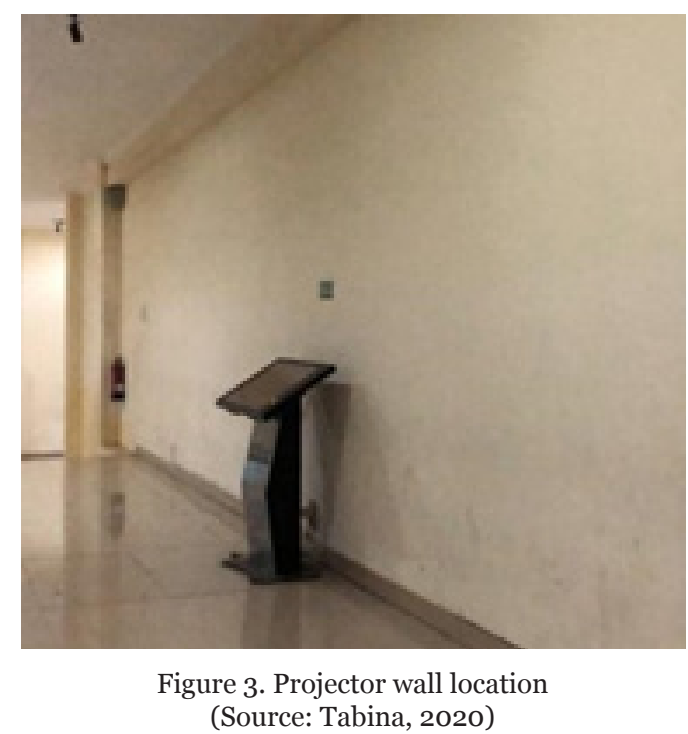

\section{Work Implementation}

The project began with an Animation Storyboard as seen in Figure 4. taken directly from the G3oS PKI film, and diorama images from the museum. Scenes were cut and selected in discussion with the museum's representatives based on actual events. 

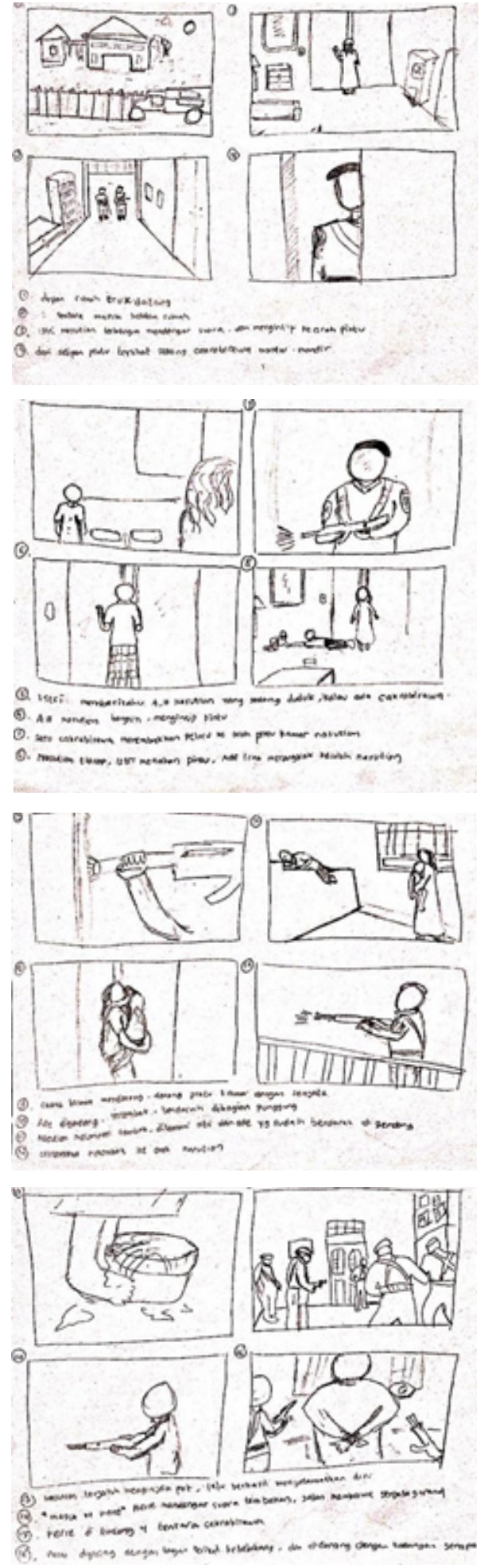

Figure 4. Storyboard 1-4 (Source: Tabina, 2020)
The next step is choosing the typeface. For scenes and pop-up screens, DIN Alternate bold is used because it has sufficient legibility on the screen. This project's colors are mostly bold, ranging from black to gray, red to green, and others. hese colors are used to draw visitors' attention, make them feel the story, while still displaying the story's dark and gloomy emotions.

Following the study's goal of increasing interaction between visitors and existing works, the animation includes interactive buttons that visitors can press to cause the animation to appear in the form of a pop-up. There are seven interactive buttons (A-G), each of which can bring up a sound for different animation scenes. The animation that appears on the screen is determined by the button that the visitor selects, as the button is set based on the position of the event. There will be a graph of the top view of the house, like a map, as a platform for the buttons on either side of the layout. Visitors can click each button any time they like because the animated window will close if the screen or another button is clicked (Figure 5).
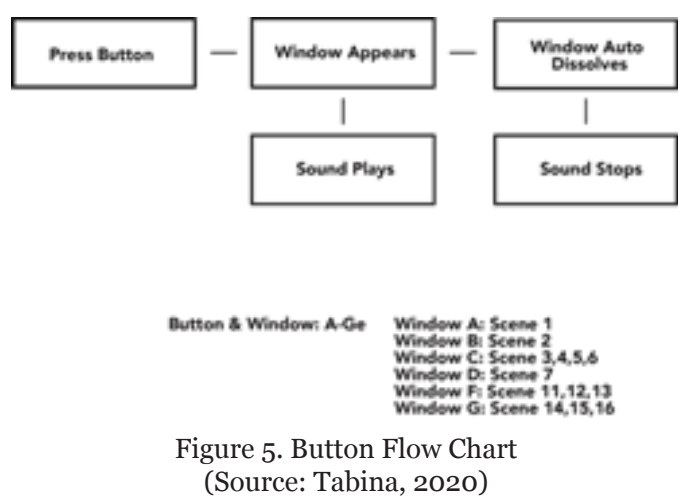

The projector interface has a symmetrical layout. The projection layout will have buttons on either side of the screen and an animation window will appear on the center of the screen. The animation will be projected by the projector. The projector will be positioned in front of two large dioramas, facing a long wall. Visitors are 
Yiesha Tabinat ${ }^{1}$

Mita Purbasari ${ }^{2}$

expected to engage with the projection and to stand approximately $30 \mathrm{~cm}$ away from the wall, so the projection will be designed to fit the measurement (Figure 6 and 7).
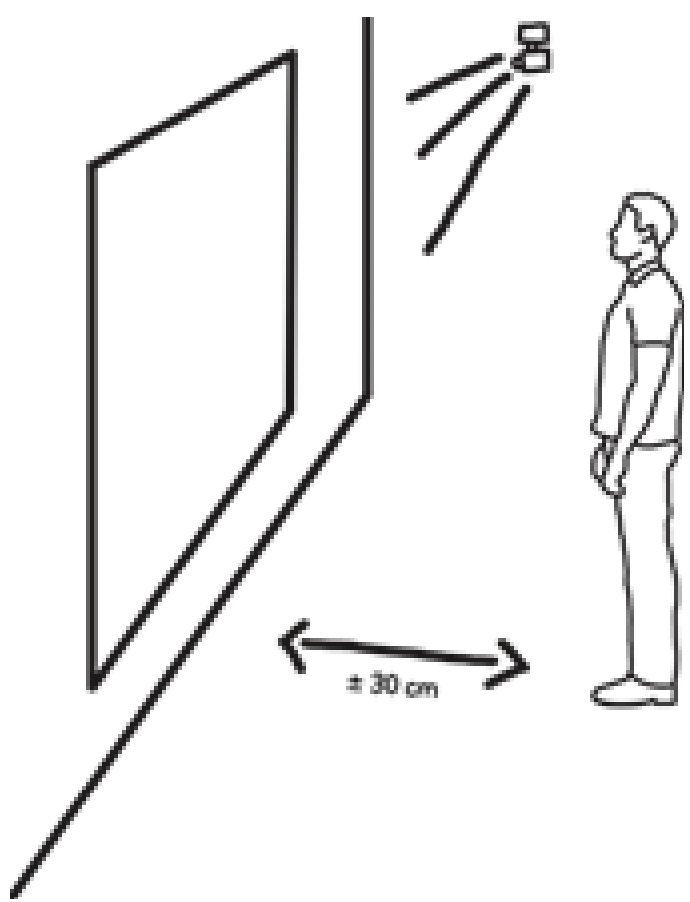

Figure 6. Estimated distance between projector and visitor

(Source: Tabina, 2020)

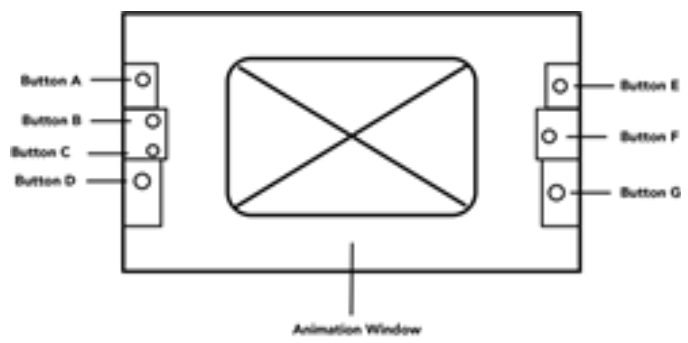

Figure 7. Projection Interface (Source: Tabina, 2020)

\section{Digital Assets}

Animation is done based on the second alternative in the storyboard. Four digital assets are used as mock-up examples.

The first scene (part A) depicts the story when a group of soldiers arrived at A.H. Nasution's house with a Dodge 500 truck.
Visualizing G30s/PKI Tragedy through Interactive Projector Media at Monumen Pancasila Sakti

It was midnight or early morning because thekidnapping occurred at 3 am (Figure 8).

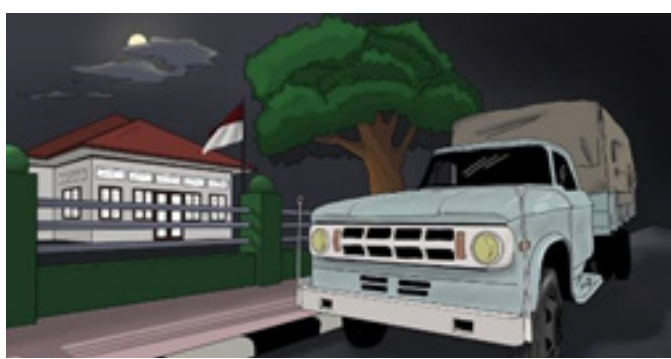

Figure 8. The first scene

(Source: Tabina, 2020)

In scene 2 (part B), the two kidnappers are seen walking inside Nasution's house. The two kidnappers are wearing uniforms and holding guns (Figure 9).

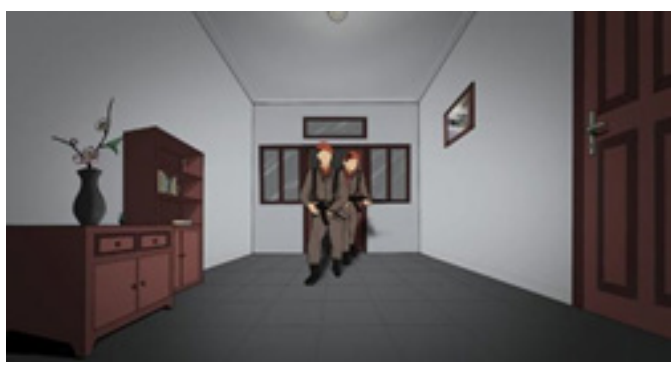

Figure 9. The scene of soldiers entering Nasution's house

(Source: Tabina, 2020)

Part $\mathrm{C}$ contains event number 3 until 6. The four events took place in the same room. This incident took place in Nasution's bedroom (Figure 10).

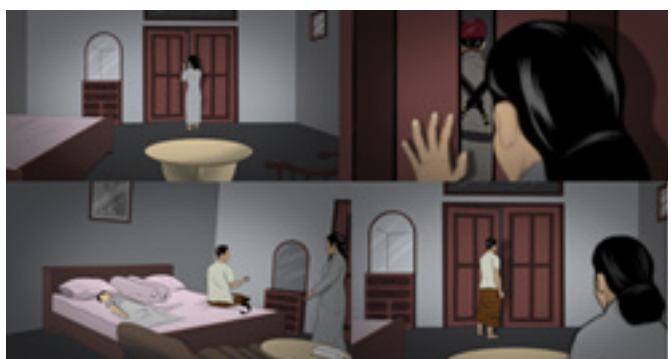

Figure 10. Four incidents inside Nasution's bedroom (Source: Tabina, 2020)

The third scene is where Nasution's wife, Johanna, hears the footsteps of the 
kidnappers outside the room. The 4th scene is where Johanna peeks through the door. The $5^{\text {th }}$ scene is where Nasution is awakened by a loud noise and is told by Johanna that there is someone outside who wants to kill him. In this scene, Ade Irma is also seen sleeping on the bed. The 6th scene is the part when Nasution stands up and checks the door.

Part D has incident number 7 which is when Nasution opens the door, a kidnapper starts shooting. It happened right at their doorstep (Figure 11).

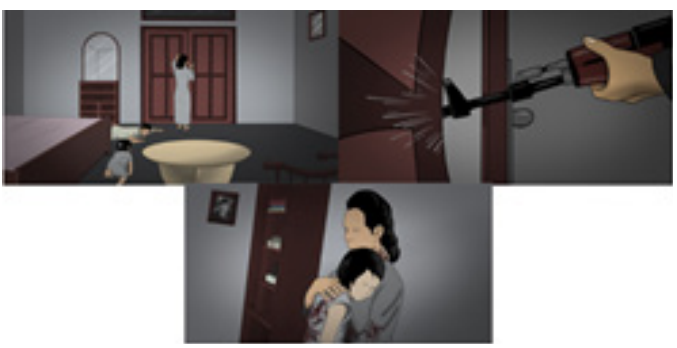

Figure 11. Three incidents during the shooting in the bedroom

(Source: Tabina, 2020)

The 8th scene is the scene where Johanna tries to close the door, Nasution squats down and Ade Irma crawls over to Nasution because he wakes up from the sound of gunfire. Scene 9 is when the kidnappers are still shooting and trying to break through. Scene 10 is the aftermath of the shooting, where Ade Irma was hit by three bullets fired by the kidnappers.

Part F contains incidents number 1113 , with the location of the incident on the side outer wall between Nasution's house and the Iraqi Embassy building. Scene 11 Nasution climbs the wall between his home and the embassy to hide, witnessed by his injured wife and daughter. Scene 12 is the kidnapper who is outside his house seeing him and trying to stop him by shooting. Scene 13 shows Nasution's point of view, when he lands on the opposite side he steps on a flower pot and injures his ankle (Figure 12).

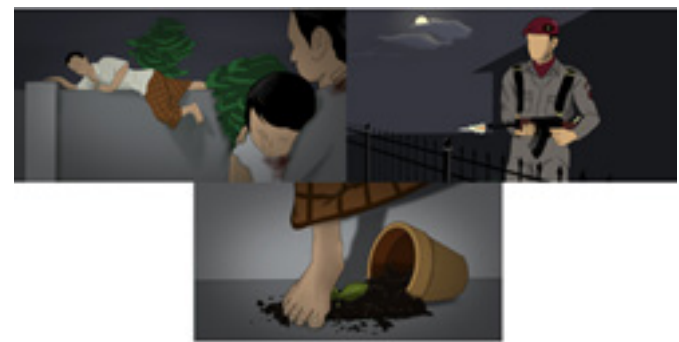

Figure 12: Nasution running away from home (Source: Tabina, 2020)

The last part is $\mathrm{G}$ which consists of 3 occurrences (14-16) as seen in Figure 13. These three scenes took place in another part of Nasution's house, the pavilion, where First Lieutenant Pierre Tendean lived. Tendean hears gunshots nearby and rushes towards the source of the sound in Scene 14. Tendean is apprehended and surrounded by a gang of kidnappers in Scene 15. The final scene, Scene 16, depicts Tendean being whisked away by two kidnappers.

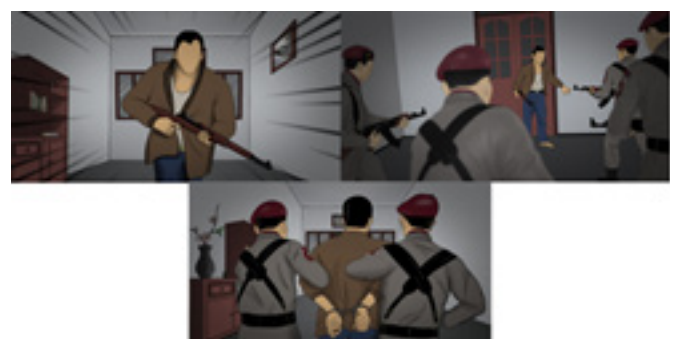

Figure 13. Arrest of Pierre Tendean (Source: Tabina, 2020)

Pop-up screen serves to provide information to the audience after interacting with the projection. Visitors are expected to touch the character in each scene, and a pop-up screen with character information will appear for a few seconds before disappearing. This feature complements the concept of creating a character in a minimalist style illustration, but a pop-up screen will help and entertain the audience at the same time, The screen will contain an original photo of the character and a little data about the character as seen in Figure 14. 
Yiesha Tabinat ${ }^{1}$

Mita Purbasari ${ }^{2}$

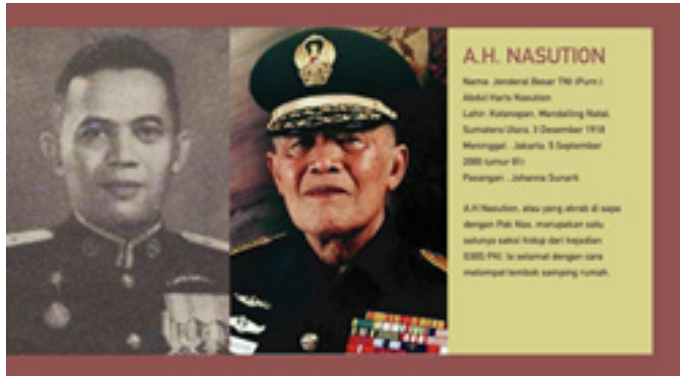

Figure 14. Pop-up screen example: A.H Nasution (Source: Tabina, 2020)

Illustrations will be animated first before being developed into interactive animations. Adobe After Effects is used as a software to animate assets. There are several steps before animating an illustration, such as dividing the asset into layers, and naming it. By doing these steps, the author will have no problems animating the assets. Unity has animation features, but the movement is restricted so it doesn't have the flexibility to move layers. Therefore, Unity is used to develop animations into interactive works.
Visualizing G30s/PKI Tragedy through

Interactive Projector Media at

Monumen Pancasila Sakti

\section{Conclusion}

As of now, museums cannot be filled with content in traditional formats such as immovable objects, especially if young people are encouraged to visit and interact with the museum. Especially when the museum is used for public events. This only draws large crowds but does not pique the visitor's interest in actually seeing and enjoying the museum's artifacts.

Interaction in the museum must involve both parties, namely the artifacts and the visitors.

Therefore, this project aims to explore the use of interactive projection and implement it into the museum itself as part of the artifact. Visitors can interact with stories and artifacts through interactive projection. This can be a fun learning experience as well as an informative one. Seeing that interactive projections were recently used by museums around the world and only one used in Indonesia, this can be an opportunity to introduce
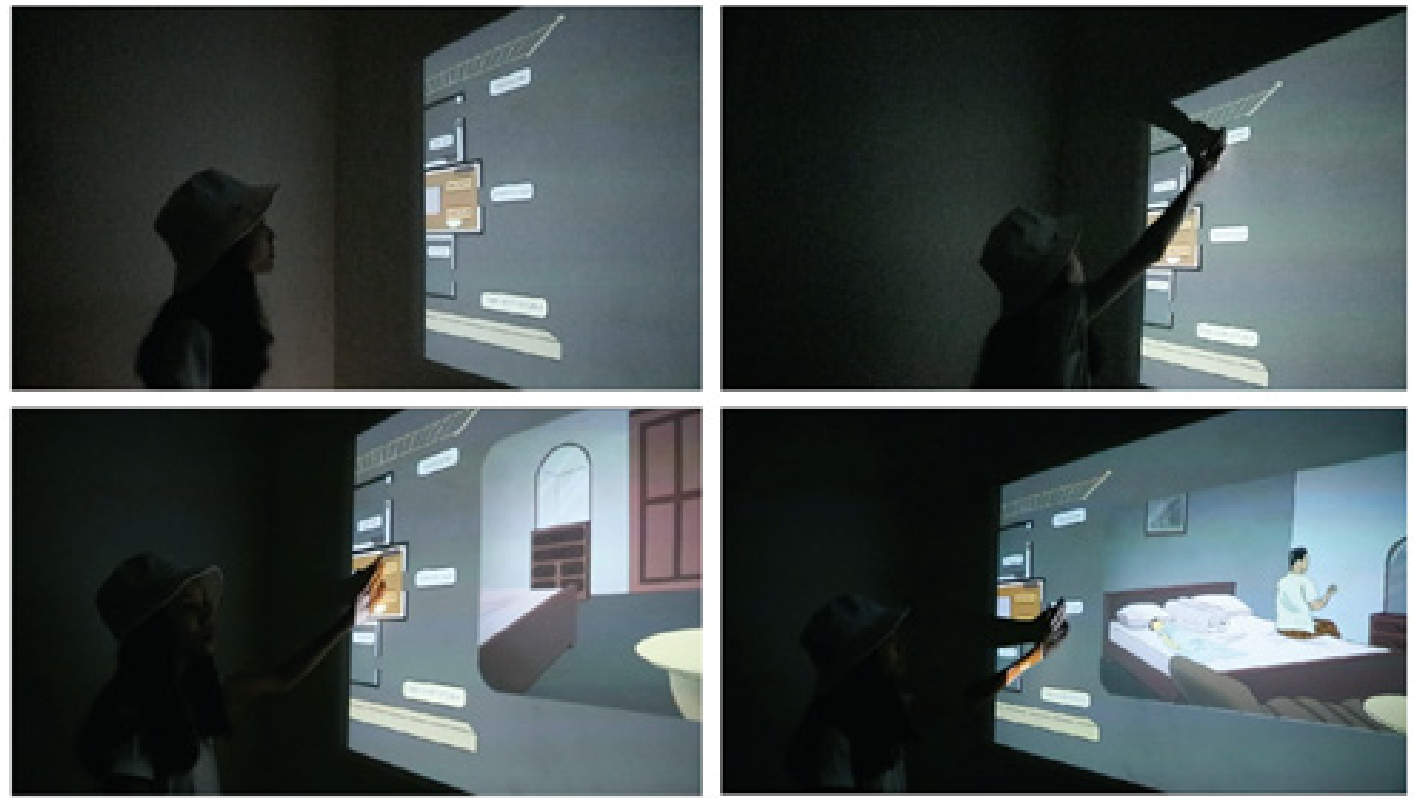

Figure 15. Visual Implementation through Interactive Projector

(Source: Tabina, 2020) 
people to a new and modern type of museum entertainment.

\section{References}

Abdalla, F. (September 21, 2017). Pengunjung Monumen Pancasila Sakti Melonjak. Retrieved from https://www. medcom.id/nasional/metro/Dkq6rBRK-pengunjung-monumen-pancasila-sakti-melonjak

Astari, P. (March 14, 2019). Mengapa Museum Indonesia Sepi Pengunjung. Retrieved from https://www.kompasiana.com/pristia3346o/5c89327eob531c53317ae55f/alasan-mengapa-museum-indonesia-sepi-pengunjung

Burlian, P. \& Damayanti, R. (2016). Patologi Sosial: Perspektif Sosiologi Yuridis dan Filosofis. Jakarta: PT. Bumi Aksara.

Chusniyah, T. (April 16, 2015) Problem dalam Perkembangan Psikologi Anak yang Berhadapan Hukum (ABH), Retrieved from http://fppsi.um.ac. $\mathrm{id} / \mathrm{p}=1278$.

Cooper, K. (August 9, 2018). Project Mapping in Events: What You Need to Know. Retrieved from https://helloendless.com/projection-mapping-inevents-need-know/

Damm, M. (2017). Lubang Buaya, Kuburan Para Pahlawan: Abjeksi dalam Historiografi Peristiwa 1 Oktober 1968. Anthropologi Indonesia, 38 (2), 105-124. https://doi/org/10.7454/ ai.v38i2.8774

Daniwati, D. (2015). Museum Ullen Sentalu dalam Perspektif Seni Budaya. Journal of Urban Society's Arts, 2 (2), 123-132. https://doi.org/10.24821/ jousa.v2i2.1449
Hamdi, M. N. H. (2020) Perancangan Museum Arkeologi di Kab. Trenggalek. (Magister Thesis). Retrieved from http://repository.untag-sby. ac.id/5085/

Tjahjopurnomo, R., Munandar A. A., Perdana, A., Rahayu, A., Gultom, A. M., Susanto, D., Asiarto, L., Supardi, N., Arbi, Y. (2011). Sejarah Permuseuman di Indonesia. Jakarta: Direktorat Permuseuman, Direktorat Jenderal Sejarah dan Purbakala, Kementerian Pariwisata dan Ekonomi Kreatif.

Krismantari, I., Aritonang, M. S., \& Razak, I. (September 30, 2015). Sept. 30, 1965 tragedy: A dark chapter in Indonesian history. Retrieved from https://www.thejakartapost.com/news/2015/o9/30/ sept-30-1965-tragedy-a-dark-chapter-indonesian-history.html.

Kusuma, M. (October 1, 2019). Jokowi: Pancasila, Benteng Indonesia Hadapi Serbuan Ideologi. Retrieved from https://www.indozone.id/ news/Z8s34e/jokowi-pancasila-benteng-indonesia-hadapi-serbuan-ideologi/read-all

RB. (nd). Revitalisasi Museum: Memang Apa Pentingnya? Retrieved from https://muspen.kominfo.go.id/berita/view?id=7

Retno, D. (August 6, 2019). Sejarah Monumen Pancasila Sakti Lubang Buaya. Retrieved from https://sejarahlengkap.com/bangunan/sejarah-monumen-pancasila-sakti

Vinta \& Septiasputri, M. D. (September 26, 2020). Saksi Bisu G3oS/PKI, Kenali Wisata Lubang Buaya. Retrieved from https://rri.co.id/humaniora/ wisata/903888/saksi-bisu-g3os-pkikenali-wisata-lubang-buaya. 
Widaningsih, Y. S. (2010). Laboratorium Sejarah Univet Bantara Sukoharjo Sebagai Sumber Pembelajaran Pendidikan Sejarah. (Magister thesis). Retrieved from https://digilib. uns.ac.id/dokumen/detail/18961/ Laboratorium-Sejarah-Univet-Bantara-Sukoharjo-Sebagai-Sumber-Pembelajaran-Pendidikan-Sejarah-Studi-Kasus-Pada-Mahasiswa-Progdi-Pendidikan-Sejarah-Univet-Bantara-Sukoharjo. (UNS-Pascasarjana Prodi Pendidikan Sejarah-S860908026-2010) 